\title{
An Agricultural Waste Based Composite to Replace or Reduce the Use of Plastics
}

\author{
Gordon Yu, Chih-Young Hung, and Hsin-Yun Hsu
}

\begin{abstract}
BioPlastics such as PLA has a few drawbacks among them incompatible with existing recycling stream and hence classified as "unrecyclable" in many countries; not truly biodegradable in natural conditions since it requires high temperature to decompose $\left(>58^{\circ} \mathrm{C}\right)$; high impact to the environment for it's high carbon footage production process; and competing to our food production for taking the corps as it's feedstock. FPC ${ }^{\mathrm{TM}}$ presented in this paper resolves all the above difficulties by using agricultural waste which contains fiber as it's main ingredient, mixed with proprietary Compatiblizer $^{\mathrm{TM}}$ which is converted starch without adding any man-made chemicals, so FPC $^{\mathrm{TM}}$ is inherently biodegradable and compostable, yet FPC $^{\mathrm{TM}}$ can be mixed with almost any plastics in any percentage, making it exhibits no harm to the existing recycling system, such characteristics also make PPC $^{\mathrm{TM}}$ to be an excellent binder to create new material from various recycled plastics including ocean plastic waste and textile waste.

Products using $100 \%$ FPCTM are not only biodegradable \& compostable, but also a truly circular bioeconomy fashion without competing with our food source, while significantly reduce air pollution because the agricultural waste would otherwise be burned off; and in the meantime create high value since the processing of biomass is not targeted to obtained low-value calories through burning, but the replacement of petro-chemical products without causing long-term burden to our land and ocean.
\end{abstract}

Index Terms-FPC ${ }^{\mathrm{TM}}$, bioeconomy, circular economy, agricultural waste processing, plastic replacement, sustainable agriculture, bioplastic.

\section{INTRODUCTION}

\section{A. Our Current Problem of Air Pollution}

Agricultural waste would have been burnt-away in many countries/areas due to it's low economic value especially in vast countries such as China and India, and FPC ${ }^{\mathrm{TM}}$ (Fiber Particulate Composite) which uses agricultural waste as its main ingredient to replace or reduce the use of plastics; is one of very effective ways to significantly reduce such possibility. UN Environmental Program 2014 Year Book calls for Air Pollution as the "World's Worst Environmental Health Risk; over 3.5 million people died each year from outdoor air pollution. Between 2005 and 2010 the death rate rose by $4 \%$ worldwide. The cost of air pollution to the world's most

Manuscript received June 6, 2017; revised April 12, 2018.

Gordon $\mathrm{Yu}$ is with the eTouch Innovation Co. Ltd., Taiwan (e-mail: gordony@etouchic.com).

Chih-Young Hung and Hsin-Yun Hsu are with National Chiao Tung University, Taiwan (e-mail: cyhung@nctu.edu.tw, hyhsu99@nctu.edu.tw). advanced economies plus India and China is estimated to be US\$3.5 trillion per year in lives lost and ill health [1].

Some fiber-based agricultural waste such as rice husks, wood chips, or corn/wheat stalks traditionally has been used as a fuel source for burning to get heat or even to generate electricity, however, due to the low heat value especially compared with coal thermal value and pricing, those applications have never reached to desirable volume scale, so the agricultural waste burning is still a major problems world-wide, especially in developing countries. By using large amount of agricultural waste as the feedstock of FPC, such air pollution can be effectively resolved.

\section{B. Our Current Problem of Plastic Waste Pollution}

Global plastics production is currently estimated to be 300 million metric tons each year and is growing at a rate of $4 \%$ annually [2]. The World Bank projects that 1.3 billion metric tons of municipal solid waste (MSW) is generated each year, a number that is expected to grow to 2.2 billion metric tons per year (MTPY) by 2025. Around $10 \%$ of the total MSW produced, or 130 Million MTPY, is plastic [3]. Since plastic waste virtually does not degrade, it persists for hundreds years after they are dumped in the dumpsites. Thus, this accumulation of plastic products is serious threat to the prospect of the ecosystem in general and to the health of human society in particular.

If products use $100 \% \mathrm{FPC}^{\mathrm{TM}}$ to replace plastic, it is fully bio-degradable and compostable, so the vast amount of plastic waste we have today can cease the accumulation for hundreds of years, effectively resolve or greatly alleviate human being's modern plastic garbage problem.

\section{Our Current Problem of Ocean Debris}

Currently ocean debris comprises mostly plastic waste which is also most damaging to marine life and eventually human's living ecosystem. Despite many urges to stop using or stop littering plastic waste to the oceans, the accumulation of plastic waste in the ocean is still increasing at least before year 2030, so far there is no feasible way to lessen the deterioration in the ocean, let alone the likely solution. Assuming the collection of ocean plastic waste can be achieved, one feasible solution is proposed at the same conference, SDGT 2017, by Yu et al., with the title of "An Optimized Pyrolysis Technology with Highly Energy Efficient Conversion of Waste Plastics into Clean Fuel While Substantially Reducing Carbon Emission" for converting the current ocean plastic waste into clean diesel, R-ONE technology, such can be constructed as an ocean petro-station to refill the diesel for the ocean liners pass by, while at the same time clean the air by reducing the sulfur emission from $10,000 \mathrm{ppm}$ to $10 \mathrm{ppm}$, another example of blue economy or 
sustainable development in the fields of waste processing and green energy.

Yet the "upstream" or future plastic infusion to the oceans can be prevented by FPC ${ }^{\text {TM }}$ which is bio-degradable in the land and under water, even when FPC ${ }^{\text {TM }}$ breaks down to pieces similar with those micro-plastic in the ocean and be eaten by fish or other marine creatures, it will cause no harm since FPC ${ }^{\text {TM }}$ is purely composed by natural plant-based by-product without any man-made chemicals or additives, so $F P C^{T M}$ is the solution for ocean plastic waste in a circular economy fashion.

\section{Our Current Problem of Less Recycling as Desired}

There are only 7 plastic recycling categories, namely PET, HDPE, PVC, LDPE, PP, PS and \#7 is "OTHER", yet there are hundreds of plastics currently in use and can only be categorized as \#7 which can't be truly recycled from conventional recycling technology which requires the same type of plastic material without mixed with others AND in a clean condition without stained by oil/dirt. Such recycling restriction exclude all composite material, all bio-plastics, lots of industrial plastics such as ABS, PC, all synthetic rubbers such as TPE, TPR, SBR, and all synthetic textile such as nylon, resin, etc. from being recycled; so the percentage of plastic recycling is quite low for conventional recycling technologies.

R-ONE ${ }^{\text {TM }}$ can turn mixed-plastic or dirty plastic into clean diesel without the need of sorting, is one effective way to increase the recycling rate of plastic significantly, the other is FPC which acts as a binder to combine different type of plastics to form a new composite which in many cases exceed the quality of single homogeneous recycled plastic. Such binder characteristics of FPC ${ }^{T M}$ greatly expand the plastic recycling rate and enrich the horizon of new breed of eco material based on waste including mixes of textile waste, ocean/marine waste, plastic waste and agricultural waste.

\section{E. Our Current Problem of De-Forestation Due to Cutting Tree}

FPC $^{\mathrm{TM}}$ is very similar to wood or paper in nature, which are all fundamentally agricultural products. There are many plastic products in the market trying to either replace wood or mimic wood, yet it's not easy to make such products completely undistinguishable from wood products especially the scent and texture. FPC ${ }^{\mathrm{TM}}$ and waste based new composite material such as $\mathrm{FPC}^{\mathrm{TM}}+$ plastic waste and/or textile waste and/or ocean/marine waste can mimic the wood products even with similar texture and scent, much closer to wood compared with conventional plastic products. FPC ${ }^{T M}$ can replace wood in many applications such as floor wood or other green building material, so the de-forestation due to cutting trees can potentially be reduced.

\section{F. Our Current Problem of Non-Sustainable Conventional Agriculture}

Pesticide and chemical fertilizer dominant conventional agriculture is non-sustainable, yet the percentage of organic farming around the world is still much less than conventional farming, one important factor is due to the pricing and availability of organic fertilizer. After bio-degradation by bacteria, FPC ${ }^{\text {TM }}$ becomes organic fertilizer similar with the fallen leaves naturally degraded in the forest. FPC based diapers, tampons, and bags mixed with organics such as urine, excrement, kitchen refuge can be composted to be used as organic fertilizer, which one day may be free of charge to all farmers if the garbage collection fees can support the processing cost. FPC ${ }^{T M}$ can possibly enable such free or very low cost organic fertilizer which leads the way towards sustainable agriculture by rapidly increase the organic farming.

\section{G. Our Objective of Sustainable Development While Creating Values towards Cradle-to-Cradle}

Conventional waste processing targets to make garbage disappear while circular economy desires to consider garbage as the feedstock for producing quality products, FPC is not only meant to make agricultural waste disappear harmlessly, but also to prevent the air pollution by burning such waste, AND also create value to make new material which replace the high-valued plastic $(\sim \mathrm{NT} \$ 50 / \mathrm{kg}$, compared with some traditional ways using agricultural waste to replace fuel such as coal which is low value, around NT $\$ 2 / \mathrm{kg}$ ), at the same time prevent the big petro-chemical plastic problem of non-degradable. FPC ${ }^{T M}$ matches both cradle-to-cradle and blue economy visions of sustainable development while creating values in a perpetual circular economy fashion.

\section{H. The Problems of Bio-Plastics}

BioPlastics (such as PLA, PHA, PBS, etc.) today has a few drawbacks, among them [4]-[8]:

1) Pricing: Typically $2 \sim 3 X$ times more expensive than conventional fossil-fuel based plastics, due to its complex and high production cost.

2) Reusable/Recyclable: Bioplastics, such as PLA (Poly Lactic Acid) cannot be recycled in many countries; it can contaminate the waste stream, reportedly making other recycled plastics unsalable, due to incompatibility between PLA and almost all fossil-fuel based plastics.

3) Competing with Food Production: Bioplastics compete for land with biofuels and food crops (as the primary feedstock is currently corn), which may make the famine or starvation for under-developed countries even worse.

4) High Impact to the Environment: Bioplastics complex production process requires large amount of fossil fuel energy and large amount of land is required to produce feedstock. Study has shown that Corn-based bioplastic emits climate change gas in landfill and some need high temperatures to decompose.

5) Disintegrable but not truly bio-degradable: The break-down phenomenon or disintegration of the Bioplastics into pieces or become microplastics which in many cases invisible to human eyes when Bioplastics are placed in natural composting site, may not be claimed as Bio-degradable, on the contrary it can possibly make the PM2.5 pollution situation getting worse. Although PLA has passed the EN 13432 and ASTM D5988 bio-degradation tests, they are all tested under the high temperature of $>58^{\circ} \mathrm{C}$, which the nature environment or the ocean water lacks of such high temperature and high humidity conditions needed for Bioplstics to be degraded in desirable period of time. Experienced farmers know the fact that PLA based mulch film can't be truly degraded in 
the field even for more than 10 years which China government is now still seeking an effective way for bio-degradable much film to resolve their severe "White Pollution" problem.

\section{FPC ${ }^{T M}$ Is a Much Better Alternative than Bio-Plastics}

There are very few carbon-footage reduction when converting corn or other crops to Bio-plastics while consuming large amount of energy, compared with fossil-fuel based plastics if the carbon-footage of growing corn also being considered; yet waste-based FPC $^{\mathrm{TM}}$ has very low or even negative carbon footage which otherwise would have been burn-away, causing more air pollution and more carbon emission; $\mathrm{FPC}^{\mathrm{TM}}$ can mix with most other non-engineering plastics in almost any percentage, a feature called "Universal Recyclable" so that FPC ${ }^{\mathrm{TM}}$ based product would not harm existing recycling stream, rather it greatly enhance the waste plastic recyclability by acting as a binder so mixed waste plastics can be reused to make valuable products which otherwise would have been end up in landfill or incinerator; $\mathrm{FPC}^{\mathrm{TM}}$ can be bio-degraded at natural temperature rather than at an elevated temperature like most Bioplastics; When volume reaches to comparable level, the cost of waste-based FPC ${ }^{\mathrm{TM}}$ will be less than petroleum-based plastic, and definitely much less than food-based Bioplastics; None of any Bioplastics complies with Circular Economy fashion while only $\mathrm{FPC}^{\mathrm{TM}}$ is sustainable in a circular economy manner, so $\mathrm{FPC}^{\mathrm{TM}}$ is definitely a much better alternative than Bio-plastics.

\section{MANufacturing Process \& PROPERTIES OF FPC ${ }^{\mathrm{TM}}$}

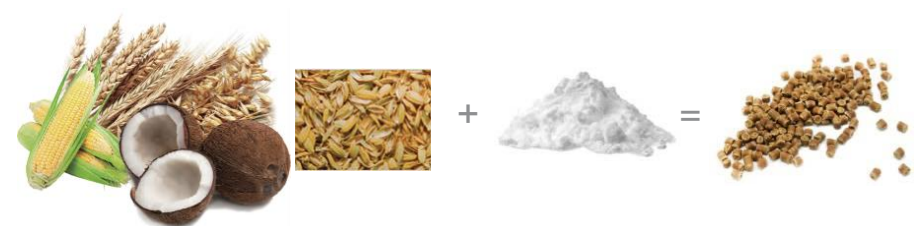

Fig. 1. Agricultural waste + Natural Compatiblizer $=\mathrm{FPC}^{\mathrm{TM}}$.

FPC $^{\mathrm{TM}}$ (Fiber Particulate Composite) is made of $100 \%$ natural ingredients from around 50 80\% agricultural waste, such as rice husk, wheat husks, corn stalks, sugarcane bagasse, palm oil residues, coconut shells, wood/bamboo chips, coffee residues, etc., virtually any plant-based farming by-products which contain fibers; and 20 50\% Compatiblizer; mainly a form of converted starch with a biological polymer additive which contains plant hormone, enzyme, vinegar and ester of lactic acid; without add-ing any man-made chemicals, as shown in Fig. 1.

The fiber feedstock is first dried and pulverized to 120 to 300 mesh, mixes well with Compatiblizer, kneaded and compressed at $110^{\circ} \mathrm{C}$ in a pressurized condition, then being extruded to form granules through a sieve with an average diameter of $3 \mathrm{~mm}$; FPC looks similar with other plastic pallets such as PP or PE.

Table I shows the properties of $\mathrm{FPC}^{\mathrm{TM}}$ [9], with references of typical fossil-fuel based common polymers such as PP and PE. Many applications traditionally use PE or PP can be replaced by FPC ${ }^{\text {TM }}$ which process is compatible with current plastic production methods, such as injection molding, thermal forming, extrusion, vacuum forming, hot pressing etc. without the need of alteration of the current production equipment. The proximity of FPC ${ }^{\text {TM }}$ properties with popular plastics enables such plastic replacement applications, especially for disposable items such as packaging material, where the feature of bio-degradation is desirable.

TABLE I: PROPERTIES OF FPC WITH REFERENCES OF PP AND PE

\begin{tabular}{|c|c|c|c|c|c|c|c|c|c|}
\hline \multicolumn{2}{|c|}{ Properties } & \multicolumn{2}{|c|}{ FPC $^{\mathrm{TM}}$} & \multicolumn{3}{|c|}{ PP } & \multicolumn{3}{|c|}{ HDPE } \\
\hline $\begin{array}{l}\text { Melt } \\
\text { Index }\end{array}$ & $\begin{array}{l}\text { ASTM } \\
\text { D1238 }\end{array}$ & $0.5 \sim 1$ & $\begin{array}{l}\mathrm{g} / 10 \\
\min \end{array}$ & $\begin{array}{l}\text { ISO } \\
1133\end{array}$ & 10 & $\begin{array}{l}\mathrm{g} / 10 \\
\mathrm{~min}\end{array}$ & $\begin{array}{c}\text { AST } \\
\text { M } \\
\text { D123 } \\
8\end{array}$ & 4 & $\begin{array}{l}\mathrm{g} / 10 \\
\min \end{array}$ \\
\hline Density & $\begin{array}{c}\text { ASTM } \\
\text { D792 }\end{array}$ & $\begin{array}{c}0.92 \sim 0 \\
.96\end{array}$ & $\begin{array}{c}\mathrm{g} / \mathrm{cm} \\
3\end{array}$ & $\begin{array}{l}\text { ISO } \\
1183\end{array}$ & 0.9 & $\begin{array}{c}\mathrm{g} / \mathrm{cm} \\
3\end{array}$ & \begin{tabular}{|c} 
AST \\
M \\
D150 \\
5
\end{tabular} & 0.96 & $\mathrm{~g} / \mathrm{cm} 3$ \\
\hline $\begin{array}{l}\text { Melting } \\
\text { Point }\end{array}$ & DSC & $\begin{array}{c}85 \sim 12 \\
5\end{array}$ & ${ }^{\circ} \mathrm{C}$ & DSC & $\begin{array}{c}120 \sim \\
170\end{array}$ & ${ }^{\circ} \mathrm{C}$ & DSC & 133 & ${ }^{\circ} \mathrm{C}$ \\
\hline $\begin{array}{l}\text { Autoigniti } \\
\text { on Temp. }\end{array}$ & -- & ca 300 & ${ }^{\circ} \mathrm{C}$ & -- & 570 & ${ }^{\circ} \mathrm{C}$ & -- & $\begin{array}{c}\mathrm{ca} \\
400 \\
\end{array}$ & ${ }^{\circ} \mathrm{C}$ \\
\hline Hardness & $\begin{array}{l}\text { ASTM } \\
\text { D2240 }\end{array}$ & $60 \pm 2$ & $\begin{array}{c}\text { Shor } \\
\text { e A }\end{array}$ & $\begin{array}{l}\text { ISO } \\
2039\end{array}$ & 107 & $\begin{array}{c}\mathrm{R} \\
\text { scale }\end{array}$ & $\begin{array}{c}\text { AST } \\
\text { M } \\
\text { D224 } \\
0\end{array}$ & 70 & $\begin{array}{c}\text { Shore } \\
\text { D }\end{array}$ \\
\hline pH Value & & $\begin{array}{c}4.5 \sim 5 . \\
5\end{array}$ & $\mathrm{pH}$ & -- & N/A & $\mathrm{pH}$ & -- & N/A & $\mathrm{pH}$ \\
\hline $\begin{array}{l}\text { Foaming } \\
\text { Rate }\end{array}$ & USIFE & 3 & -- & $\begin{array}{l}\text { USI } \\
\text { FE }\end{array}$ & 3 & -- & $\begin{array}{c}\text { USIF } \\
\text { E }\end{array}$ & 3 & -- \\
\hline $\begin{array}{l}\text { Elongatio } \\
\text { n }\end{array}$ & $\begin{array}{l}\text { ASTM } \\
\text { D1623 }\end{array}$ & $\begin{array}{c}260 \pm 1 \\
0\end{array}$ & $\%$ & $\begin{array}{l}\text { ISO } \\
527\end{array}$ & 500 & $\%$ & $\begin{array}{c}\text { AST } \\
\text { M } \\
\text { D638 }\end{array}$ & $\begin{array}{c}100 \\
0\end{array}$ & $\%$ \\
\hline $\begin{array}{l}\text { Tensile } \\
\text { Strength }\end{array}$ & $\begin{array}{l}\text { ASTM } \\
\text { D1623 }\end{array}$ & $26 \pm 2$ & $\begin{array}{l}\mathrm{kg} / \\
\mathrm{cm} 2\end{array}$ & $\begin{array}{l}\text { ISO } \\
527\end{array}$ & 350 & $\begin{array}{l}\mathrm{kg} / \\
\mathrm{cm} 2\end{array}$ & $\begin{array}{c}\text { AST } \\
\text { M } \\
\text { D638 }\end{array}$ & 310 & $\mathrm{~kg} / \mathrm{cm} 2$ \\
\hline $\begin{array}{l}\text { Flexural } \\
\text { Modulus }\end{array}$ & $\begin{array}{c}\text { ASTM } \\
\text { D790 }\end{array}$ & $\begin{array}{c}35810 \\
\pm 60 \\
\end{array}$ & $\begin{array}{l}\mathrm{kg} / \\
\mathrm{cm} 2\end{array}$ & $\begin{array}{l}\text { ISO } \\
178\end{array}$ & $\begin{array}{c}1400 \\
0\end{array}$ & $\begin{array}{l}\mathrm{kg} / \\
\mathrm{cm} 2\end{array}$ & $\begin{array}{c}\text { AST } \\
\text { M } \\
\text { D790 }\end{array}$ & $\begin{array}{c}125 \\
00\end{array}$ & $\mathrm{~kg} / \mathrm{cm} 2$ \\
\hline
\end{tabular}

\section{RESUlTS AND DisCUSSION}

\section{A. Replacement of Plastics}

FPC ${ }^{\text {TM }}$ can be used by itself; Product made by $100 \%$ FPC is truly bio-degradable and compostable, which is perfect for disposable items or packaging material (Fig. 2). However, the physical strength may not be as good as plastics in certain applications.

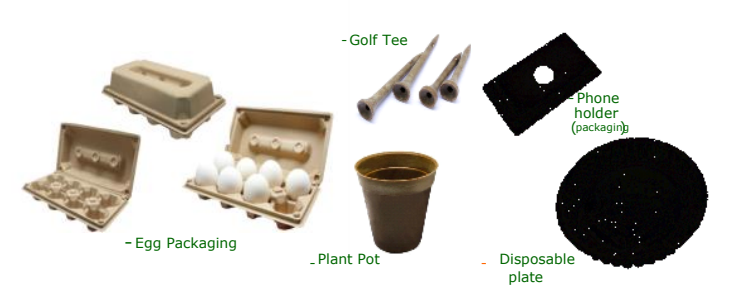

Fig. 2. 100\% made from $\mathrm{FPC}^{\mathrm{TM}}$ for the replacement of plastics

\section{B. Biodegradable}

FPC material analysis done by SGS [10] through FTIR concludes that the FPC spectrum is similar to Poly(DL-Lactide)-CO-Glycolide (PLGA, Table II), which is an USA FDA approved therapeutic copolymer owning to its biodegradability and biocompatibility [11]. 
Tesr Result

TABLE II: FPC ${ }^{\mathrm{TM}}$ MATERIAL ANALYSIS BY SGS

\begin{tabular}{|c|c|c|}
\hline Test Item & Test Method & Test Result \\
\hline Material Analysis & $\begin{array}{c}\text { FTIR(Fourier Transform } \\
\text { Infrared } \\
\text { Spectrophotometer) }\end{array}$ & $\begin{array}{c}\text { Sample's spectrum is similar to } \\
\text { Poly(DL-Lactide)-CO-Glycolide } \\
\text { through the comparison with } \\
\text { date base }\end{array}$ \\
\hline
\end{tabular}

Note:1Brand and model of FTIR: Varian3100

A recent $\mathrm{FPC}^{\mathrm{TM}}$ analysis done by Professor Hsin-Yun Hsu's research team at National Chiao Tung University measures the FPC spectrum of $1700 \mathrm{~cm}^{-1}$ (Fig. 3), reconfirm the test result by SGS, for the FPC spectrum similar to one of the spectrum of Poly(DL-Lactide)-CO-Glycolide which is $1752 \mathrm{~cm}^{-1}$ (Fig. 4).

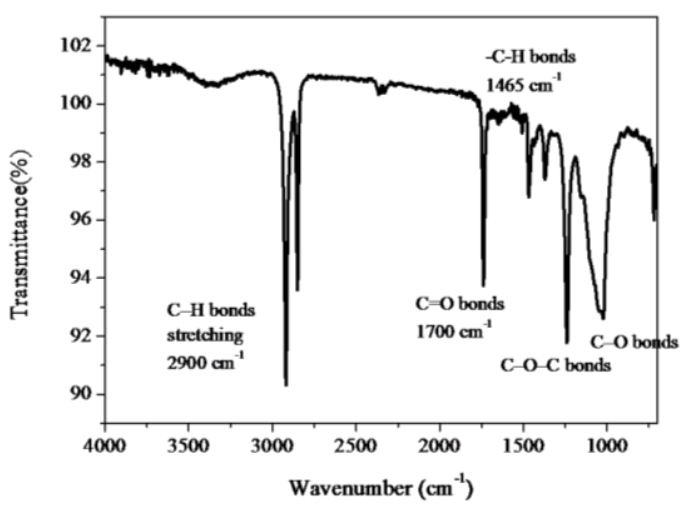

Fig. 3. FTIR Spectrum of FPC ${ }^{\mathrm{TM}}$.

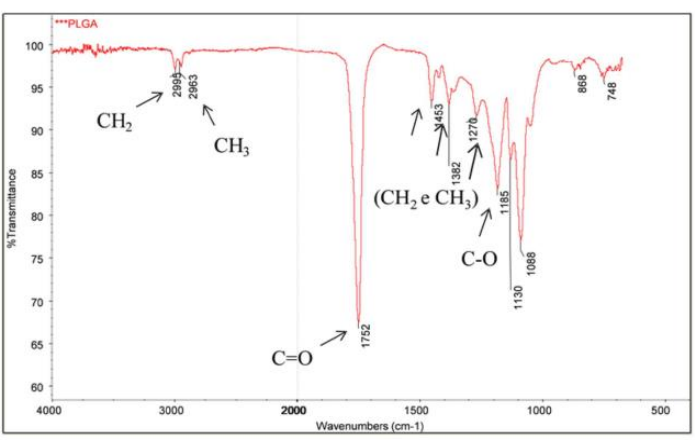

Fig. 4. FTIR spectrum of biodegradable LPGA [12]

Although field test of biodegradability varies dependent on finished products, in general it takes about 1 2 years for FPC to be fully degraded at typical Taiwan outdoor temperature under soil. The end-of-life of $100 \% \mathrm{FPC}^{\mathrm{TM}}$ products can be converted to organic fertilizer through easily available room temperature composting, compliant with EU's $1^{\text {st }}$ deliverable of Circular Economy Package with new rules on organic and waste-based fertilizers in March of 2016 [13]. Works are undergoing to develop $\mathrm{FPC}^{\mathrm{TM}}$ based diapers and tampons; if those are mixed with organics such as urine, excrement, kitchen refuge sealed with a biodegradable bag, then such organic waste can be sent to composting factory to make organic fertilizer, greatly reduce the volume of today's municipal solid waste, while up-cycling to create value towards sustainable agriculture.

C. FPC ${ }^{T M}$ as a Binder to Maximize the Plastic Recycling
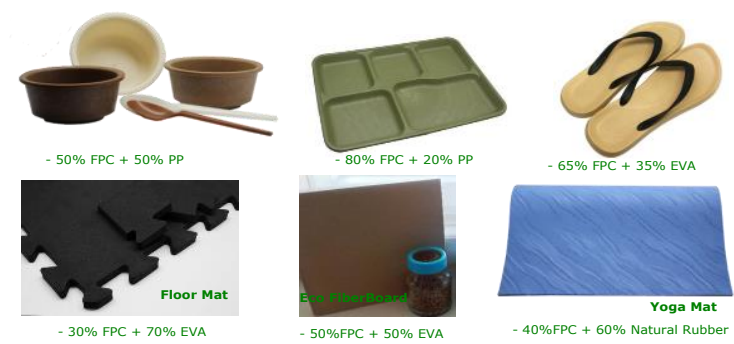

Fig. 5. Products with mixes of FPC ${ }^{\mathrm{TM}} \&$ plastics.

FPC $^{\mathrm{TM}}$ can effectively reduce the use of plastics by substituting portions of plastics with $\mathrm{FPC}^{\mathrm{TM}}$, if the percentage of such mixed compound is carefully chosen, it will not degrade the quality or performance compared with it's $100 \%$ plastic counterparts. Traditionally different plastics can't be mixed arbitrarily, yet worst cases are bio-plastics such as PLA which can possibly harm our existing recycling system due to it's incompatibility with almost all other plastics; However, FPC ${ }^{\mathrm{TM}}$ can be mixed perfectly with most plastics or rubbers, such as PP, PE, PS, PVC, EVA or natural Rubber, synthetic rubbers (SBR, TPR, TPE) and even PLA etc. (Fig. $5)$ in any combination ratio from $0 \sim 100 \%$. Such characteristics make FPC ${ }^{\mathrm{TM}}$ is not only recyclable by itself, but also would not harm our existing recycling system by being compatible with all plastics in any percentage, a feature we called "Universal Recyclable ${ }^{\mathrm{TM}}$ ", which is capable of maximizing the waste plastic recycling by re-utilizing those previously considered "unrecyclable mixed plastics".

\section{Up-Cycling Capability}

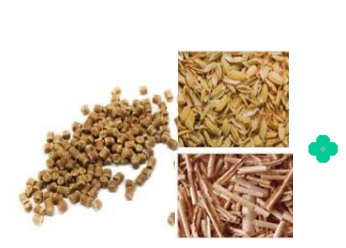

$55 \%$ FPC

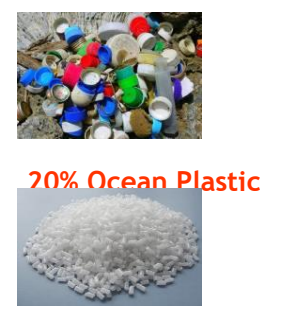

$25 \%$ Plastic

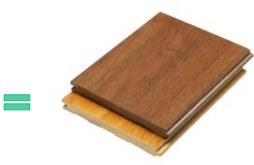

CJ Board
Fig. 6. Wood-floor like product using 55\% FPCTM \& $20 \%$ ocean plastic waste.

When carefully chosen the percentage of FPC $^{\text {TM }}$ and plastic waste, the strength and characteristics of such new composite can be even better or desirable than plastic or wood. Fig. 6 is a product made from $55 \% \mathrm{FPC}^{\mathrm{TM}}$ with $20 \%$ ocean plastic waste; the "Up-cycling" capability of FPC enables the use of varies waste such as ocean waste, and textile or fabric waste for example, green building material made from $70 \% \mathrm{FPC}^{\dagger \mathrm{M}}+30 \%$ PET/Cotton blended textile waste as shown in Fig. 7.

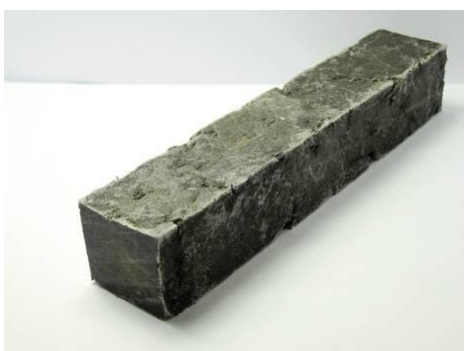

Fig. 7. $70 \% \mathrm{FPC}^{\mathrm{TM}}+30 \% \mathrm{PET} /$ Cotton blended textile waste. 
The bicycle pedal made from $70 \% \mathrm{FPC}^{\mathrm{TM}}+30 \%$ Plastic/rubber (Fig. 8) has won the Environmental Award of EuroBike 2016, which is also better performance/quality and smell better without pungent scent than most plastic/rubber counterparts.

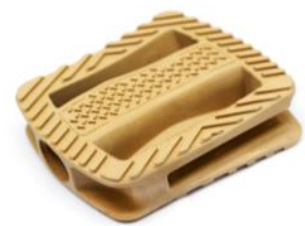

Fig. 8. Bike pedal with 70\% $\mathrm{FPC}^{\mathrm{TM}}$ has won the Environmental Award of EuroBike 2016.

TABLE II: FPC ${ }^{\mathrm{TM}}$ YOGA MAT COMPARISON WITH 100\% NR

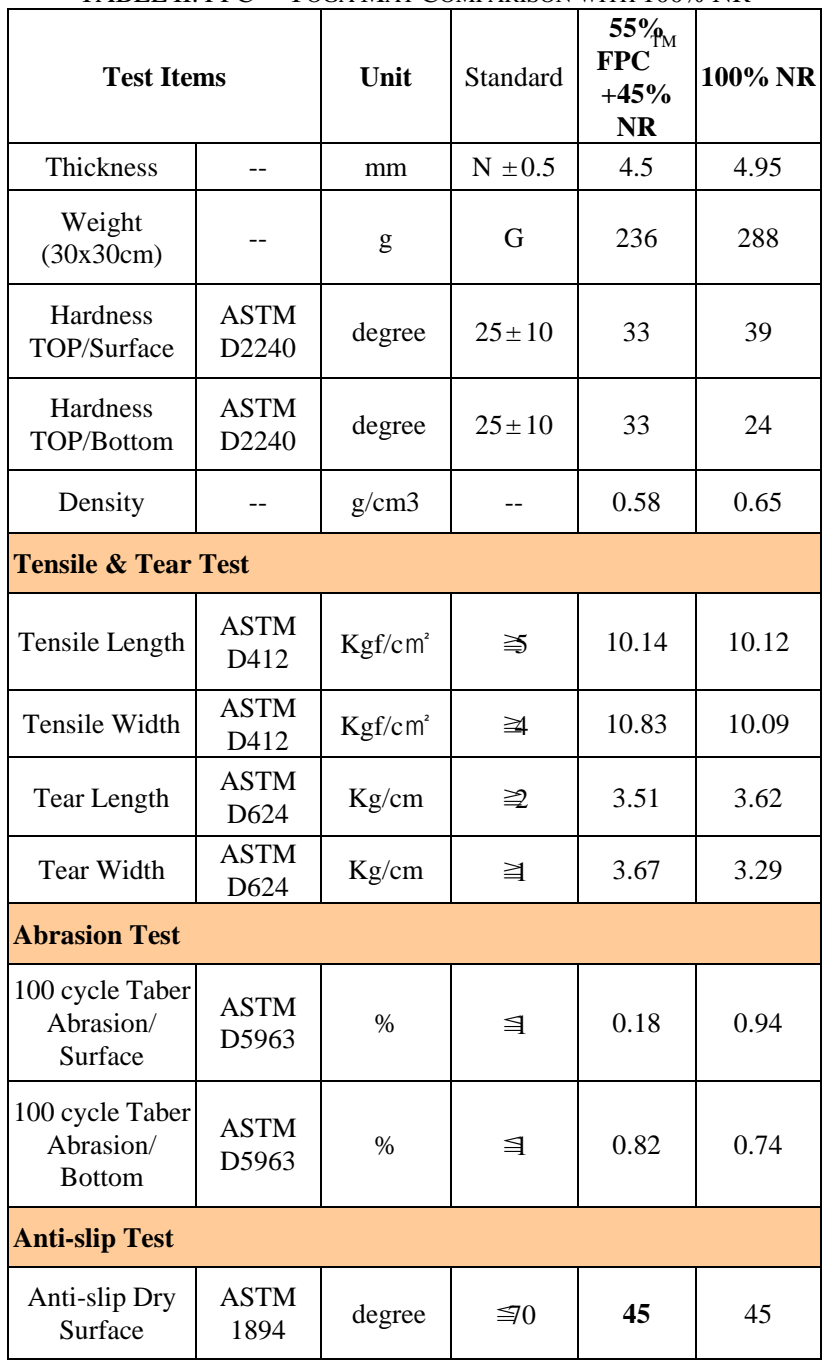

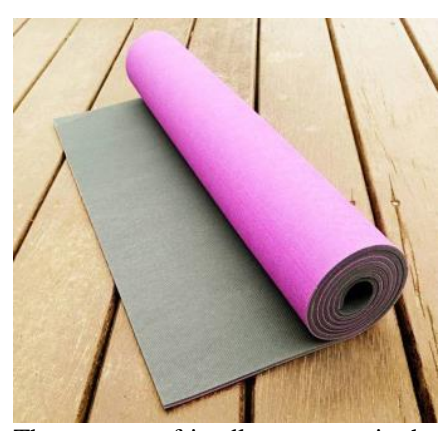

Fig. 9. The most eco-friendly yoga mat in the world.

Compared with all of the performance/quality data between $55 \% \mathrm{FPC}^{\mathrm{TM}}+45 \% \mathrm{NR}$ (Natural Rubber) and $100 \%$
NR, as shown at Table II, FPC ${ }^{\mathrm{TM}}$ yoga mat is not only the most eco-friendly yoga mat in the world (Fig. 9), but also with the same or better performance/quality than $100 \% \mathrm{NR}$ yoga mat [14].

\section{E. Healthier than Fossil-Fuel Based Plastics}

FPC $^{\mathrm{TM}}$ based product does not have the pungent smell typically associated with the new plastic/rubber products, instead it emits the light fragrance of plant which is healthier especially for floor mats/Yoga mats which will be closely in contact with human bodies.

Green building products such as Eco FiberBoard (made by $50 \% \mathrm{FPC}+50 \%$ EVA) contains zero (0) Methanal (Formaldehyde), which is not only with low or zero carbon footage, but also a healthier products in terms of smell and Methanal content.

\section{F. Clean Technology}

Unlike the paper mill industries, there is no need of water for $\mathrm{FPC}^{\mathrm{TM}}$ manufacturing process except for small volume of circulation cooling water. The only emission or by-product of $\mathrm{FPC}^{\mathrm{TM}}$ is water vapor or clean water. No air, sound and water pollutions.

\section{CONCLUSION}

$\mathrm{FPC}^{\mathrm{TM}}$ is a very versatile fiber-based composite material derived from agricultural waste capable of replacing the use of plastics, if products are made of $100 \% \mathrm{FPC}^{\mathrm{TM}}$, it's fully biodegradable and compostable; if products are made of combination of $\mathrm{FPC}^{\mathrm{TM}}$ and other plastics, in addition to effectively reduce the use of plastics, the FPC ${ }^{\mathrm{TM}}$ acting as a binding agent can also maximize the reuse of waste mixed-plastic where traditionally those can't be recycled, while creating value by making a better performance or quality product due to Up-cycling feature. The truly biodegradable feature can possibly foster the opportunity to rapidly increase the organic farming by converting the plastic-like $\mathrm{FPC}^{\mathrm{TM}}$ to organic fertilizer, a sustainable development example while reducing air pollution and creating values in a circular economy and cradle-to-cradle fashion.

\section{ACKNOWLEDGEMENT}

Special gratitude to Taipei City Government for a research grant on FPC yoga mat, eTouch Innovation Co. Ltd. product development team and National Chiao Tung University research teams.

\section{REFERENCES}

[1] United Nations Environmental Program, "YEAR BOOK 2014 Emerging Issues in Our Global Environment".

[2] Plastics Europe. Plastics - The facts 2013. [Online]. Available: http://www.plasticseurope.org/documents/document/2013101409582 4final_plastics_the_facts_2013_published_october2013.pdf

[3] The World Bank, "What a waste: A global review of solid waste management," March 2012.

[4] K. Flint, "Biodegradable plastic: Its promises and consequences," Applied Sciences, DUJS Winter 2013.

[5] L. Shen, "Product overview and market projection of emerging bio-based plastics," PRO-BIP 2009, Final Report, June 2009.

[6] Scientific American, "The environmental impact of corn-based plastics," June 2008. 
[7] Á.-C. C. Rosalía et al., "Sustainability of bio-based plastics: General comparative analysis and recommendations for improvement," Journal of Cleaner Production, vo. 23, issue 1, March 2012, pp. 47-56.

[8] J. Vidal, "Sustainable bio-plastic can damage the environment," The Guardian, April 26, 2008.

[9] US Patent \#8,389,110 B2 granted Mar. 5, 2013.

[10] SGS Taiwan Ltd., Test Report \#KV-09-04962XA-1, Product: "Fiber Particulate Composite FPC01", July 7, 2009.

[11] H. K. Makadia and S. J. Siegel, "Poly lactic-co-glycolic acid (PLGA) as biodegradable controlled drug delivery carrier," Polymers, 2011.

[12] R. G. Sousa et al., "Synthesis, characterization, and study of PLGA copolymer in vitro degradation," Journal of Biomaterials and Nanobiotechnology, vol. 06, no. 1, 2015.

[13] Report from the Commission of the European Parliament and the Council on the implementation of the Circular Economy Action Plan, P3, Legislative proposal on fertilizers, March 2016.

[14] Plant fiber-based Composite Yoga Mat, Taiwan ROC Patent \#M544961, granted 7/11/2017.

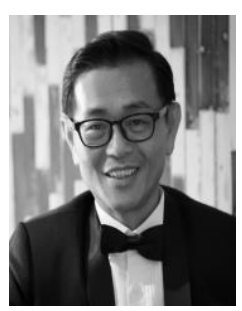

Gordon Yu got the MSEE 1987 University of Texas, Arlington, Texas USA; the BSEE 1979 National Chiao Tung University, Hsinchu, Taiwan.

$\mathrm{He}$ is currently the CEO of Etouch Innovation Co. Ltd., Managing Director \& Chief Strategy Officer of EVP, Chief Strategy Officer of UWin Nanotech, and Managing Director of Taiwan Hsinchu Green Industry Association, all based in Taiwan. More than 150 patents holder in Taiwan, China, USA and EU, he has been awarded Taiwan $9^{\text {th }}$ "Innovative research Award" by Minister of Economic Affairs, $5^{\text {th }}$ "Rising Star Award" by the Prime Minister, and $11^{\text {th }}$ "National Award of Outstanding SME" by the President of Taiwan.

Mr. Yu has been a frequent invited Speaker for Sustainability around the world such as "International Conference on Solid Waste, Hong Kong, May 2015, "ECO Technology Show" Brighton, UK, June 2015, "Global Bioeconomy Summit", Berlin, Germany, Nov. 2015, "International Conference on Synergy between Science and Social Development in Solid Waste Management", Hong Kong, Sept,. 2016, and "EU-Taiwan Green Summit: Moving towards a Circular Economy and Sustainable Trade", Taipei, Nov. 2016, etc. Mr. Yu is a member of Taiwan Cradle-to-Cradle
Alliance and a Board member of Taiwan Hsinchu Green Industry Association.

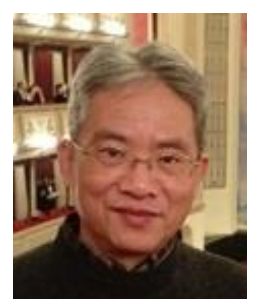

Chih-Young Hung earned his B.S in electrical engineering from National Chiao Tung University, Hsinchu, Taiwan in 1979, MA in management from Sonoma State University, Rohnert Park, CA, USA, in 1984, and Ph.D. in finance from Texas Tech University, Lubbock, Texas USA in 1990

He worked for ERSO/ITRI as an assistant R\&D engineer for two years. His main task involved the design and implementation of circuit board for an industrial robot's controller. He joined and remains at his current job as a professor at the National Chiao Tung University since 1990. He has published several books and also papers in various academic journals. His main research interests are in the area of technology foresight, assessment and selection.

Professor Chih-Young Hung is the Honorary Chairman of the Chinese Valuation Association, Taiwan. He is a board member of the Chinese Society of the Management of Technology.

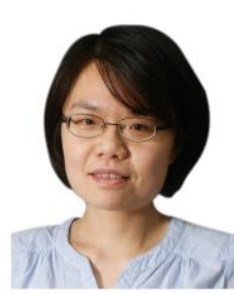

Hsin-Yun Hsu received the B.S. and M.Sc. degrees from the National Taiwan University, Taipei, Taiwan, in 2001 and 2003, respectively, with the disciplines in agricultural chemistry and biomedical engineering. She received the Ph.D. degree from the Natural and Medical Sciences Institute at the University of Tübingen, Germany, in 2008.

Between 2008-2010, she worked at Kazusa DNA Research Institute, Japan. She is currently the faculty in Department of Applied Chemistry/Institute of Molecular Science, National Chiao Tung University, Taiwan. Her research interests have included the fabrication of eco-friendly, biocompatible micro/nanoparticulate systems for biosensing and drug delivery applications. She also developed high-throughput bead-based assays for the identification of biomarkers in various diseases. 